EDUKACJA MIĘDZYKULTUROWA

2018, nr 1 (8)

ISSN 2299-4106

DOI: $10.15804 / \mathrm{em} .2018 .01 .20$

AnNa Szafrańska

Aleksandra Minczanowska

\title{
„Edukacja małego dziecka. Konteksty społeczne, międzykulturowe i oświatowe”. \\ Cieszyn - Ustroń - Czeski Cieszyn, 26-27 października 2017
}

W dniach 26-27 października 2017 roku w Cieszynie, Ustroniu i Czeskim Cieszynie odbyła się międzynarodowa konferencja naukowa z cyklu Edukacja Matego Dziecka. Konferencja - organizowana po raz piąty w cieszyńskim ośrodku akademickim - stanowiła kontynuację zapoczątkowanego przed kilku laty cyklu międzynarodowych spotkań naukowych, poświęconych edukacji małego dziecka w Polsce i na świecie. Organizatorzy to osoby reprezentujące Uniwersytet Śląski (Wydział Etnologii i Nauk o Edukacji w Cieszynie), Uniwersytet Ostrawski (Wydział Pedagogiczny), Uniwersytet w Bańskiej Bystrzycy (Wydział Pedagogiczny), Uniwersytet Borysa Grinczenki w Kijowie (Wydział Pedagogiczny), Centrum Pedagogiczne dla Polskiego Szkolnictwa Narodowościowego w Czeskim Cieszynie oraz Stowarzyszenie Wspierania Edukacji Międzykulturowej. Tradycyjnie konferencja miała charakter interdyscyplinarny, a tematyka została skoncentrowana m.in. wokół takich zagadnień, jak:

- społecznych i kulturowych kontekstów współczesnych przemian edukacyjnych,

- teoretycznych i praktycznych aspektów wychowania przedszkolnego i integralnej edukacji wczesnoszkolnej,

- reformowania edukacji i zmian programowych,

- procesu kształcenia i jego ewaluacji w kontekście potrzeb dziecka,

- problemów kształcenia i pracy nauczycieli w warunkach zróżnicowania kulturowego,

- zadań i perspektyw przedszkolnej i wczesnoszkolnej edukacji międzykulturowej.

Jako podstawowe formy obrad obowiązywały rozmowy, dyskusje oraz sesje warsztatowe, dotyczące teoretycznych i praktycznych aspektów działalności edukacyjnej z małym dzieckiem w przedszkolu i w szkole. 
Konferencję otworzyły przewodniczące Komitetu Naukowego i Organizacyjnego konferencji prof. dr hab. Ewa Ogrodzka-Mazur oraz dr hab. Urszula Szuścik. Profesor Ewa Ogrodzka-Mazur nawiązała do założeń stojących u podstaw cyklicznych naukowych spotkań skoncentrowanych wokół idei edukacji małego dziecka. Wskazała na potrzebę rozpatrywania tego zagadnienia w kontekście nowo pojawiających się wyzwań - w tym związanych ze zróżnicowaniem kulturowym współczesnego świata. Z ramienia oficjalnych władz Uniwersytetu Śląskiego wystąpił dr hab. Andrzej Kasperek - Prodziekan Wydziału Etnologii i Nauk o Edukacji ds. Naukowych i Współpracy z Zagranicą. Pomysł spotkań w ramach Edukacji Małego Dziecka od początku miał charakter nastawiony na międzynarodową współpracę - jej praktycznym wymiarem jest rozpatrywanie podejmowanych zagadnień z uwzględnieniem od pierwszej konferencji - perspektywy czeskiej i słowackiej. W związku z tym kolejno zabrały głos przedstawicielki współorganizatorów prof. PhDr. Bronislava Kasáčová, PhD. (Pedagogická fakulta, Univerzita Mateja Bela Banská Bystrica, Słowacja), doc. PaedDr. Radmila Burkovičová, PhD. (Univerzita v Ostravě, Republika Czeska) oraz mgr Marta Kmet' (Dyrektor Centrum Pedagogicznego dla Polskiego Szkolnictwa Narodowościowego w Czeskim Cieszynie).

W ramach konferencji zostały zorganizowane dwie sesje plenarne, sesja posterowa, sesja wyjazdowa, warsztaty oraz prowadzone były obrady w sekcjach tematycznych. Uczestnicy konferencji reprezentowali 17 szkół wyższych z 4 krajów, Ośrodek Doskonalenia Zawodowego Nauczycieli oraz Instytut Rozwoju Małego Dziecka. Łącznie w konferencji wzięły udział 54 osoby.

Pierwsza z sesji plenarnych Społeczne i oświatowe konteksty wspótczesnych przemian rodziny, przedszkola i szkoty zawierała sześć wystąpień. Za szczególnie istotne - w kontekście wyzwań stojących przed edukacją przedszkolna i wczesnoszkolną - należy uznać wystąpienie prof. dr hab. Danuty Waloszek - Metodologia badań dzieciństwa. Wstępny zarys obszaru poszukiwań i pytań badawczych. Pani Profesor wskazywała, jak ważne są działania prowadzące do ujednolicenia językowego w świecie teorii i badań nad dzieciństwem. Podkreślała znaczenie dbałości o metodologiczny wymiar realizowanych badań w tym obszarze. W tej części obrad został poruszony przez prof. PaedDr. Alenę Douškovą, PhD., i prof. PhDr. Soňie Karikovą, PhD. (Univerzita Mateja Bela, Słowacja) wątek z zakresu edukacji międzykulturowej. Panie Profesor zajęły się w swoich badaniach centrami kształcenia dla Słowaków żyjących poza granicami swojego kraju (Vzdelávacie centrá pre Slovákov žijúcich $v$ zahraničí a ich podpora pri príprave detí na komisionál- 
ne skúšky). Słowacja jest krajem doświadczającym na dużą skalę migracji (zwłaszcza młodych) ludzi. W latach 2000-2014 liczba Słowaków pracujących za granicą wzrosła prawie trzykrotnie. Wprawdzie nie ma oficjalnych statystyk dotyczących dzieci mieszkających w związku z emigracją rodziców poza granicami kraju, ale samo zjawisko - jak podkreślały Panie Profesor wymaga szczególnej uwagi ze względu na budowanie społeczności imigracyjnej i realizowanie polityki państwa w stosunku do Słowaków mieszkających za granicą. Brak statusu mniejszości w innych krajach powoduje ograniczone możliwości zaspokajania potrzeb edukacyjnych dzieci w języku słowackim. Działania rodziców z tych społeczności spowodowały powstanie licznych ośrodków edukacyjnych i szkolnych. Ich działalność powinna być, zdaniem prelegentek, szczególnie uważnie obserwowana i wspierana.

Kolejnym punktem spotkania była sesja wyjazdowa Dziecko $w$ tradycji i kulturze Śląska Cieszyńskiego. W Muzeum Śląska Cieszyńskiego w Cieszynie została przeprowadzona lekcja muzealna - wzbudzająca wiele emocji i pytań wśród uczestników. Zajęcia zostały przeprowadzone przez dr hab. Grzegorza Studnickiego - pracownika Instytutu Etnologii i Antropologii Kulturowej w Cieszynie. Kolejnym punktem sesji wyjazdowej było spotkanie w Centrum Pedagogicznym dla Polskiego Szkolnictwa Narodowościowego w Czeskim Cieszynie. Mgr Barbara Kubiczek wprowadziła uczestników konferencji w problematykę funkcjonowania szkół z polskim językiem nauczania w Republice Czeskiej. Zaprezentowane zostały materiały metodyczne opracowywane w Centrum, przedstawione efekty realizowanych grantów transgranicznych, których beneficjentami są najczęściej szkoły - nauczyciele i uczniowie.

Po powrocie na miejsce obrad (Dom Wczasowy Jawor w Ustroniu) goście konferencyjni mieli okazję uczestniczyć w sesji posterowej Konteksty międzykulturowe w edukacji małego dziecka. Pierwszy dzień obrad zakończył warsztat Madry śmiech w edukacji, czyli jak z lekcji nie zrobić cyrku - prowadzony przez dr hab. prof. UKW Przemysława Pawła Grzybowskiego.

Kolejny dzień obrad rozpoczęła II sesja plenarna zatytułowana Proces edukacji w kontekście potrzeb dziecka. Większość wystąpień skoncentrowana była wokół edukacji przedszkolnej i szkolnej. Z zakresu edukacji wielo - i międzykulturowej były trzy wystąpienia. W pierwszym z nich - Wartości cenione przez najmtodsze pokolenie Polaków i ich cele życiowe - zasoby indywidualne $i$ wspólnotowe w budowaniu kapitatu Pogranicza - prof. dr hab. Ewa Ogrodzka-Mazur (UŚ Katowice, Wydział Etnologii i Nauk o Edukacji w Cieszynie) przedstawiła analizę zgromadzonego w latach 2004-2005 oraz 2015-2016 materiału badawczego. W analizie problematyki kompetencji społecznych 
Autorka przyjęła konceptualizację teoretyczną, nawiązującą do propozycji Michaela Argyle'a klasyfikacji trudnych sytuacji społecznych, Tadeusza Lewowickiego teorii zachowań tożsamościowych oraz koncepcji zadań rozwojowych w ujęciu Roberta J. Havighursta. Założyła, że kompetencje społeczne są wzorcami zachowania społecznego i jako złożone, specyficzne umiejętności, nabywane przez dziecko w toku różnorodnych doświadczeń, warunkują efektywne radzenie sobie w określonego typu sytuacjach społecznych. Uzyskane dane pozwoliły na porównanie, a następnie wskazanie podobieństw i różnic występujących między badanymi grupami uczniów z pogranicza polsko-czeskiego w zakresie cenionych przez nich wartości oraz nabywanych kompetencji społecznych. Z kolei prof. dr hab. Hristo Kyuchukov (UŚ Katowice, Wydział Etnologii i Nauk o Edukacji w Cieszynie) w wystąpieniu Do the preschool Turkish children in Berlin know Turkish zwrócił uwagę na zagadnienie znajomości języka tureckiego przez dzieci tureckie mieszkające w Niemczech. Ważne, chociaż trudne zagadnienie zostało podjęte przez dr hab. prof. UKW Przemysława Grzybowskiego (Uniwersytet Kazimierza Wielkiego w Bydgoszczy). W prezentacji zatytułowanej Chorowanie, cierpienie i umieranie w lekturach dla małego dziecka Autor podkreślał, że ideą edukacji międzykulturowej jest spotkanie Innego/Obcego, a następnie wejście z nim w dialog, zapoznanie się z jego światem, osobiste doświadczenie jego odmienności i zrozumienie dlaczego jest właśnie taki. Spotkaniu mogą towarzyszyć różne emocje - również takie, jak strach, niepewność czy niechęć. Jednak właściwie zorganizowane spotkanie, dostarczenie odpowiednich informacji pozwalają zamienić je w pozytywne zainteresowanie, tolerancję czy akceptację. Taką funkcję oswajania dzieci z różnymi, czasami trudnymi tematami, pełnią również książki, które mogą być wykorzystywane zarówno jako lektury w domu, jak i książki pomocnicze na zajęciach w szkołach, różnych instytucjach, a także podczas wszelkiego rodzaju działań w przestrzeni publicznej.

Po obradach plenarnych organizatorzy zaplanowali trzy sekcje tematyczne. W pierwszej z nich było 8 wystąpień skoncentrowanych wokół tematu sekcji: W poszukiwaniu wspótczesnego modelu bycia nauczycielem. Wśród nich trzy osoby przedstawiły zagadnienia związane z sytuacją nauczycieli w środowisku zróżnicowanym. Dr Łucja Reczek-Zymróz (PWSZ w Krośnie) przygotowała wystąpienie na temat Preferowane wartości we wspótczesnym modelu bycia nauczycielem wczesnej edukacji: na przyktadzie badań porównawczych przeprowadzonych na terenie południowej Polski (województwo małopolskie) oraz pótnocnych i południowych Węgrzech (Kaposvari, Sarospatak). W kolejnym doc. PhDr. Mgr. Jaroslav Balvín, CSc. (Univerzita Tomáše 
Bati w Zlíně) przedstawił sytuację dzieci romskich w szkołach (Romové, škola a romské ditě). W tradycyjnej kulturze romskiej dzieci romskie są wychowywane bez udziału szkoły. Uczą się umiejętności swoich rodziców i dziadków, podążając za ich przykładem. Wielu romskich rodziców miało i nadal nie ma zaufania do szkoły, co często zapobiegało i nadal uniemożliwia małym dzieciom uczęszczanie do szkoły. To sprawia, że szkoła i nauczyciele stoją przed wieloma wyzwaniami w celu objęcia dzieci romskich procesem edukacji. Również kolejne wystąpienie dotyczyło kwestii związanych z sytuacją nauczyciela pracującego z romskimi dziećmi. Dr Łukasz Kwadrans (Wydział Etnologii i Nauk o Edukacji w Cieszynie) w wystąpieniu Wspomaganie pracy nauczyciela w warunkach zróżnicowania kulturowego - instytucja asystenta romskiego przedstawił krótką charakterystykę pracy asystenta romskiego, historię wprowadzenia tej instytucji do polskich szkól, a także możliwości i obszary współpracy z nauczycielem przedmiotu, wychowawcą klasy, pedagogiem szkolnym i dyrektorem. Podkreślał, że asystent romski pełni aktualnie rolę mediatora, przewodnika, tłumacza i wspomaga również funkcjonowanie ucznia romskiego w szkole oraz relacje z jego rodzicami, rodziną.

W kolejnej w sekcji Determinanty jakości edukacji przedszkolnej i wczesnoszkolnej znalazły się wystąpienia dotyczące działań profilaktycznych i diagnostycznych, metodyki nauczania oraz środków dydaktycznych wykorzystywanych na tych etapach nauczania. Obrady rozpoczęła dr Ewa Kowalska, koncentrując się na potrzebie i możliwościach wykorzystania biografii jako źródła wiedzy o dziecku i dla dziecka. W kolejnych wystąpieniach prelegentki skoncentrowały się na miejscu i determinantach edukacji polonistycznej, matematycznej i ogólnotechnicznej w młodszym wieku szkolnym. Podczas tej sesji można było usłyszeć również o stereotypach i dylematach związanych z funkcjonowaniem żłobków, a także o trudnościach edukacyjnych ujawniając nieprawidłowości w zakresie organizacji procesu kształcenia w oparciu o wykorzystanie podręcznika szkolnego.

W ostatniej sekcji Współczesne przestrzenie edukacji małego dziecka wystąpili Mgr. et Mgr. Daniel Hanuš, LL.M. (MBA Evropský polytechnický institut, s.r.o, vysoká škola) oraz doc. PaedDr. Radmila Burkovičová, PhD. (Uniwersytet Ostrawski), którzy przedstawili aktualne podstawy prawne kształcenia na etapie wychowania przedszkolnego w Republice Czeskiej ( $A k$ tuální praktické právni souvislosti predškolního vzděláváni v České republice). W każdej z sekcji obrady kończyła dyskusja wokół tematów poruszonych przez poszczególne osoby. 
Drugi dzień obrad zakończyło podsumowanie konferencji, podczas którego moderatorzy z poszczególnych sekcji, prezentując podjęte przez prelegentów wątki, zwracali uwagę na konieczność ciągłego podejmowania problematyki edukacji małego dziecka w kontekście społeczno-kulturowych przemian, warunków zróżnicowania kulturowego, reform i zmian programowych oraz wynikających z nich konieczności zmian w procesie kształcenia i przygotowania nauczycieli. W imieniu organizatorów - dr hab. Anna Szafrańska - dziękując uczestnikom za bardzo ciekawe i merytoryczne wystąpienia, podkreśliła znaczenie osobistego wkładu poszczególnych naukowców w wymianę wiedzy, doświadczeń, myśli i poglądów w tak ważnej współcześnie tematyce edukacji małego dziecka. 